\title{
Online casinos: advertising and avoidance among Generation $Y$ consumers in Sweden
}

\author{
Julia Henriksen $^{1} \cdot$ Malin Hornebrant $^{1} \cdot$ Adele Berndt $^{1}$ (D)
}

Received: 7 May 2021 / Accepted: 15 December 2021 / Published online: 7 January 2022

(C) The Author(s) 2022

\begin{abstract}
Online casinos are one of Sweden's largest gambling sectors. Increased advertising investment and advertising frequency have sought to attract Generation Y consumers to these casinos, yet it has been suggested that advertising can contribute to avoidance behaviours towards products and services, including online casinos and specific gambling brands. The various advertising aspects used in gambling advertising and their impact on behaviour have not been widely researched. Thus, the purpose of this study was to explore the use of creative strategies in casino advertising and how it contributes to the avoidance of online casinos, specifically among Swedish Generation Y consumers. As an exploratory study, qualitative methods were used. Initially, 13 casino advertisements were analysed to identify the strategies used in the advertisements. These were then presented to Generation Y consumers in three focus groups and six in-depth interviews. The analysis of the advertising shows the use of people and characters in presenting the casino brand. Male voice-overs were utilised in addition to music and other casino-related sounds. The advertising also used bright colours to attract attention. The impact of these advertisements is that the content, the auditory cues rather than just music, the emotional response, and the frequency of the advertising were found to contribute to the avoidance of casino brands. Furthermore, the ethics and general attitudes to the industry impact the decision to avoid these brands. The managerial implication of this research shows the impact of advertisements on the decision to avoid a brand, specifically a casino brand.
\end{abstract}

Keywords Online casinos · Advertising $\cdot$ Avoidance $\cdot$ Generation Y · Advertising strategies

Adele Berndt

adele.berndt@ju.se

Julia Henriksen

henriksenjulia@gmail.com

Malin Hornebrant

malin94@live.se

1 Jönköping International Business School (JIBS), P O Box 1026, 551-11 Jönköping, Sweden 


\section{Introduction}

Gambling involves staking money on uncertain outcomes in the future (McMillen 2005). Increasingly, gambling occurs online, including sports betting, online lotteries, and online casinos. Online casinos make up the second largest sector of the online gambling market (Gainsbury et al. 2013) and accounted for $40 \%$ of all gambling in Sweden in 2018 (Spel Inspektionen 2018).

Despite the regulation of gambling advertising, it is described as pervasive in modern society, becoming increasingly sophisticated (Binde and Romild 2019; Torrance et al. 2021a). Similar to other advertising, gambling advertising has the purpose of building relationships and increasing the time and money spent (Binde 2014; Binde and Romild 2019; Deans et al. 2016; Labrador et al. 2021). Online casinos have increased their advertising spend by 95\% since 2016 (Spel Inspektionen 2019a), with increased frequency and wider reach, thus dominating casino advertising (Håkansson and Widinghoff 2019). This phenomenon is not limited to Sweden, with increased marketing spend by gambling companies in countries like Australia and the United Kingdom (UK), highlighting the importance of this topic both in society and to Generation Y (Miller 2018; Torrance et al. 2021a, b).

Generation Y consumers, born between 1977 and 1994 (Noble et al. 2009), are increasingly engaging in online gambling. Generation Y members are more likely to gamble online in their homes than in physical casinos (Griffiths and Barnes 2008), preferring skill-based and interactive games over chance-based games (Suh et al. 2017). In 2018, 21\% of gamblers in Sweden were members of Generation Y (the largest group), playing for "fun and excitement" (Spel Inspektionen 2019b). In March 2019, 40\% of individuals who had used the Swedish national gambling self-exclusion website (Spelpaus.se) were from this cohort group (Spel Inspektionen 2019a). As they are more likely to engage in online gambling, Generation $\mathrm{Y}$ individuals serve as future consumers for online casinos.

The increased advertising spend on gambling and increased gambling behaviour has resulted in the development of an anti-consumption movement that recognises the impact of gambling on the broader society and at an individual level. Anti-consumption - that is, the act of deliberately avoiding any form of consumption (Lee et al. 2009b) - is suggested to be triggered by excessive unsustainable consumption and the shift in power from brands to consumers by referring to their ability to ignore and resist efforts from marketers (Denegri-Knott et al. 2006; Pentina and Amos 2011). Anti-consumption can be generalised for the consumption of all products and services as well as for specific products or brands, such as gambling or casino brands (Garcia-Bardidia et al. 2011). The importance of the negative aspects of branding are increasingly acknowledged, with researchers arguing it is as important to understand why consumers avoid a specific product or brand (Fournier et al. 2012; Hogg and Banister 2001; Knittel et al. 2016; Lee et al. 2009b).

Brand avoidance can be viewed as a "phenomenon whereby consumers deliberately choose to keep away from or reject a brand" (Lee et al. 2009a; p. 422) and can contribute to negative brand equity, including a lower return on investment 
(Aaker 1996; Lee et al. 2009a). Due to the impact customers deliberately avoiding a brand has on the organisation, it is imperative that managers understand what causes this choice. Research regarding brand avoidance is relatively limited, and research within specific industries is recommended (Berndt et al. 2019; Knittel et al. 2016). Previous research has analysed gambling advertising (Deans et al. 2016; Håkansson and Widinghoff 2019; Korn 2005; Labrador et al. 2021; McMullan and Kervin 2012), but research into the advertising strategies used to impact branding, specifically attitudes and behaviours, is limited (Clemens et al. 2017; Nyemcsok et al. 2018; Torrance et al. 2021a). With the increased frequency and advertising spend on casino advertising as well as the lack of research into gambling advertising and the specific advertising components, the purpose of this study was to explore the use of creative strategies in casino advertising and how it contributes to the avoidance of online casinos, particularly among Swedish Generation Y consumers.

Two research questions were formulated to attain the purpose of the research, namely:

1. What advertising strategies are used in gambling advertising?

2. How do these advertising strategies affect the avoidance of casino brands?

This research contributes to the further understanding of gambling advertising in other countries among this cohort group beyond the UK and Australia, as suggested by Torrance et al. (2021a). This is important, given this group's relevance to the gambling industry (Suh et al. 2017). Moreover, this study examines how these advertising strategies impact the decision to avoid online casino brands (i.e., brand avoidance). This research contributes to a better understanding of brand avoidance, specifically advertising factors related to online casino brands.

The paper presents the theory of advertising as a type of brand avoidance and the previously identified factors that can be considered. The methodology is then presented, including the identification of the advertisements and the participants for the study. The findings of the advertising analysis and qualitative methods are then identified. The paper concludes with the discussion, limitations, and future research opportunities.

\section{Literature review}

\section{Anti-consumption}

Anti-consumption can be described as resistance, distaste or being against consumption, and can be viewed as a reflection of a lifestyle (Amine and Gicquel 2011; Lee et al. 2011; Zavestoski 2002) to achieve societal and personal goals (Garcia-Bardidia et al. 2011), with consumers deciding not to consume a range of products or services. At an individual level, this reflects an individual's overall (non)consumption of specific products or services (Iyer and Muncy 2009) by not purchasing 
these products. Diverse objects of anti-consumption have been identified, including products and brands as well as organisations, market ideology and consumer culture (Amine and Gicquel 2011) driven by a range of purposes, including personal, ethical, and societal issues (Cambefort and Pecot 2020). In the case of online casino gambling, the societal impacts of gambling are recognised as a reason for anti-consumption and lead to brand avoidance.

\section{Types of brand avoidance}

Previous research (Lee 2008; Lee et al. 2009a; Mostert et al. 2021) has identified four major types of brand avoidance as well as a fifth category-advertising (communication) avoidance (Berndt et al. 2019; Knittel et al. 2016; Mostert et al. 2021; Odoom et al. 2019). The first major type of brand avoidance is experience avoidance, which arises from poor or negative experiences with the product, including poor performance and inconvenience (Coulter 2009; Lee et al. 2009a). This means that the customer has had a negative encounter with the organisation and, as a result, decides not to buy or support the organisation in the future. The second type of brand avoidance, identity avoidance, results from a difference between the brand identity and the customer's self-identity (Lee et al. 2009a; Mostert et al. 2021). As consumers select brands based on the image they wish to project (Dall'Olmo Riley and De Chernatony 2000), they will avoid a brand that does not support this image. Moral avoidance is the third type of brand avoidance that accrues from differences in values between the parties, where customers decide to avoid brands that conflict with their moral values, beliefs, and ethics (Rindell et al. 2014; Sandikcı and Ekici 2009). Therefore, country of origin, anti-hegemony, and corporate ethics can serve as reasons for consumers to avoid a brand (Bloemer et al. 2009; Kozinets and Handelman 2004). The fourth major type of brand avoidance is derived from the customers' perceptions that the product does not provide the expected value for money, as evidenced in the value of the product or service to the consumers (Bolton and Drew 1991). Consequently, the consumers avoid a brand as they do not perceive that it provides value for money (Lee et al. 2009c).

An additional or fifth category of avoidance, namely advertising avoidance, was also identified (Knittel et al. 2016). This type of avoidance proposes that advertising (or marketing communication) used by the organisation as the sender can contribute to the consumer deciding not to purchase the brand (Knittel et al. 2016; Mostert et al. 2021; Odoom et al. 2019), which is the focus of this study.

\section{The nature of advertising}

Advertising is defined as "brand-initiated communication intent on impacting people" (Dahlén and Rosengren 2016 p. 359) that communicates about an organisation, product, service, or idea from an identified sponsor. Various models (e.g., AIDA, Information Processing, hierarchy of effects) suggest that advertising can influence customers by attracting attention, ending in an action or a response from the audience (Belch and Belch 2015; Pitt et al. 2018). These models start by attracting 
attention, thus creating awareness and attitudes that are achieved using advertising. The attitude towards advertising as well as the techniques and appeals used in the advertisements (Haytko et al. 2018; Sandage and Leckenby 1980) impact outcomes like brand attitudes, purchase and other behaviours (Haytko et al. 2018; Mehta 2000; Oumlil and Balloun 2020; Petrovici and Marinov 2007). This means that casino advertising can be used to create positive attitudes and attract new gamblers, although the extent to which casino advertising can attract new gamblers has been questioned (Hing et al. 2014).

Previous research indicates that advertising and advertising strategies may not only create positive responses but can also cause negative emotions (e.g., irritation) and have a behavioural outcome where an individual may decide to avoid or stay away from a brand (Berndt et al. 2019; De Pelsmacker and Van Den Bergh 1999; Dolliver 2010; Knittel et al. 2016; Mostert et al. 2021). Casino advertising includes both paid advertising and promotions embedded in television programming, which makes gambling more interesting (Hing et al. 2017). The Internet provides additional opportunities to reach customers, expanding how the organisation can communicate with the audience (Belch and Belch 2015). Concern has been expressed regarding gambling advertising, with a fear that advertising encourages excessive gambling, especially when it takes place online, which means the impulse to gamble can be acted upon immediately (Hing et al. 2017, 2019).

\section{Advertising strategies}

Advertisements comprise several strategies that are used to communicate with the audience and create the desired consumer response. This includes aspects related to the content, celebrity endorsers, music, the response to advertisements, and the frequency of advertisements that have been suggested as contributing to brand avoidance (Knittel et al. 2016; Odoom et al. 2019).

The content, namely the message or storyline within advertisements can result in avoidance when it is perceived as distasteful (Harris Interactive 2010; Odoom et al. 2019). For example, brands using taboo themes can affect consumers' attitudes and purchase intentions (Sabri and Obermiller 2012). The most common messages in gambling advertisements are gambling wins and bonuses, virtual socialisation, escapism, and gambling as a form of excitement (Deans et al. 2016; Gavriel Fried et al. 2010; Håkansson and Widinghoff 2019; Korn et al. 2005; McMullan and Kervin 2012). Casino advertising tends to show the positive aspects associated with winning (Abarbanel et al. 2017; Derevensky et al. 2010; Labrador et al. 2021) and fun (Sklar and Derevensky 2011), with many adverts showing the ease of access, reflecting a glamourous lifestyle and attractive people (Hing et al. 2015, 2017). These messages suggest that it is easy to achieve success, happiness, and wealth through gambling (Binde 2014; Torrance et al. 2021b), but do not report the low possibility of winning nor the risks associated with gambling (Gavriel Fried et al. 2010). 
Using a celebrity endorser, an organisation aims to associate the celebrity with the brand and positively influence perceptions and attract attention (Binde 2014; Fill and Turnbull 2016). Celebrity endorsers are used to project their image onto the brand (McCracken 1989), which means that the positive attitudes towards the celebrity are transferred to the brand (Apéria and Back 2004). This strategy has been used in gambling advertising, where sports stars act as the face of the brand (Pitt et al. 2018). For example, the online casino brand LeoVegas has utilised Frank Andersson and Dolph Lundgren as celebrity spokespeople in its advertisements (Friberg Wennerberg 2018).

The music used in advertisements can influence the perception of the brand, impacting emotional reactions like affection and memories (Apaolaza-Ibáñez et al. 2010; Bramley et al. 2016). For example, when music is perceived as too loud, distasteful or irrelevant, it can lead to avoidance (Lantos and Craton 2012). The choice of music genre is important due to its appeal to specific target markets and the congruity of the music with the images in the advertisement and the target market (Alpert et al. 2005; Oakes 2007). Previous casino research shows that the music genre used in casinos aligns with the customer profile and elicits diverse emotions in casino patrons (Bramley et al. 2016).

The emotional response to seeing an advertisement is crucial, as negative emotions are transferred from the advertisement to the brand (Dens et al. 2008), impacting avoidance. Examples include when an advertisement is perceived as annoying (De Pelsmacker and Van Den Bergh 1999; Knittel et al. 2016). Highly emotional advertising or provocative advertising can also lead to brand avoidance due to the reaction to these advertisements (Swani et al. 2013).

Advertising frequency is necessary for brand awareness, with a high number of repetitions increasing the persuasion and advertising recall (Alwitt and Mitchell 1985). Alwreikat and Rjoub (2020) found that repetitive advertising resulted not only in irritation, but also reduced levels of customer engagement. Consequently, finding a balance between too much and too little advertising is necessary to gain the positive effects, while also limiting the negative effects (Chih-Chung et al. 2012). Derevensky et al. (2010) found that individuals express a dislike for gambling advertising because of its frequent prevalence. Frequency has been associated with the type of shows broadcast, with $28 \%$ of advertisements linked to reality shows and $3 \%$ connected to news broadcasts (Håkansson and Widinghoff

Table 1 Summary of strategies identified in theory

\begin{tabular}{l} 
Content \\
$\begin{array}{l}\text { The message or storyline contained in the advertisement and includes the appeal } \\
\text { Celebrity endorsers }\end{array}$ \\
$\begin{array}{l}\text { The use of a well-known person to associate the celebrity with the brand } \\
\text { The music selection can reinforce the broader message contained in the advertise- } \\
\text { ment }\end{array}$ \\
$\begin{array}{l}\text { Emotional response } \\
\text { Thequency }\end{array}$ \\
$\begin{array}{l}\text { The number of times the advertisement is broadcast, which is necessary for } \\
\text { awareness to develop }\end{array}$ \\
\hline
\end{tabular}


2019). A summary of the advertising strategies impacting brand avoidance identified in theory appears in Table 1.

\section{Methodology}

To attain the goals of the study, qualitative research was used due to the ambiguous nature of the topic (Babin and Zikmund 2016). Advertisements were identified and presented in focus groups and interviews, similar to Korn et al. (2005) and McMullan Kervin (2012), and as recommended by Binde (2014). Thus, the research started with the identification of advertising of online casinos and was followed by qualitative data collection methods, specifically focus groups and interviews.

\section{Selection of the advertisements}

Advertisements from on-demand television were obtained (Henriksen and Hornebrant 2019) as this medium is more commonly watched than regular television, specifically by younger generations (Frick 2018). One on-demand channel (Viaplay) was selected, as $21.2 \%$ of Swedish households are subscribed to this service, which broadcasts standardised (rather than personalised) advertising (Myndigheten för Press 2018). The advertisements were recorded over 7 days, covering a range of times (i.e., from 8:00 until 02:00 the following day) over different 3-h-long periods of the day (e.g., 8:00-11:00) and focussed on three major channels (Channel 3,5 and TV 6) (see Table 2). In total, 13 advertisements for online casinos were collected and presented to the participants. As no advertisements contained any aspects of celebrity endorsement, this aspect could not be included in the study.

\section{Analysis of the advertisements}

Visual content analysis (Bell 2001) was used to analyse the advertisements as they can be regarded as "potent semiotic texts" (Butkowski and Tajima 2017). This analysis suggests the development of specific categories that reflect various variables and values in the images and is similar to previous research (Korn et al. 2005; Pitt et al.

Table 2 Recording of advertising

\begin{tabular}{lllllll}
\hline & $08: 00-11: 00$ & $11: 00-14: 00$ & $14: 00-17: 00$ & $17: 00-20: 00$ & $20: 00-23: 00$ & $23: 00-02: 00$ \\
\hline $\begin{array}{l}\text { Monday } \\
\text { Tuesday }\end{array}$ & $\times$ & $\times$ & $\times$ & $\times$ & \\
$\begin{array}{l}\text { Wednesday } \\
\text { Thursday }\end{array}$ & $\times$ & $\times$ & $\times$ & $\times$ & $\times$ & \\
$\begin{array}{l}\text { Friday } \\
\text { Saturday }\end{array}$ & $\times$ & $\times$ & $\times$ & & $\times$ & \\
Sunday & $\times$ & $\times$ & $\times$ & $\times$ & & $\times$ \\
\hline
\end{tabular}


Table 3 Details on the focus groups' participants

\begin{tabular}{llll}
\hline Focus group number & $\begin{array}{l}\text { Number and gender of } \\
\text { participants }\end{array}$ & Duration & Previous gambling experience \\
\hline 1 & $6(3 \mathrm{M}, 3 \mathrm{~F})$ & $105 \mathrm{~min}$ & "Yes"=2; "no" =4 \\
2 & $6(4 \mathrm{M}, 2 \mathrm{~F})$ & $93 \mathrm{~min}$ & "Yes" = 3; "no" =3 \\
3 & $6(3 \mathrm{M}, 3 \mathrm{~F})$ & $99 \mathrm{~min}$ & "Yes" = 3; "no" =3 \\
\hline
\end{tabular}

Table 4 Detail on the interview participants

\begin{tabular}{llll}
\hline $\begin{array}{l}\text { Participant } \\
\text { number }\end{array}$ & Gender & Duration & $\begin{array}{l}\text { Previous } \\
\text { gambling } \\
\text { experience }\end{array}$ \\
\hline 1 & Male & $66 \mathrm{~min}$ & Yes \\
2 & Male & $72 \mathrm{~min}$ & No \\
3 & Male & $58 \mathrm{~min}$ & Yes \\
4 & Female & $64 \mathrm{~min}$ & No \\
5 & Female & $78 \mathrm{~min}$ & No \\
6 & Female & $62 \mathrm{~min}$ & Yes \\
\hline
\end{tabular}

2018). Similar to methods used by Håkansson and Widinghoff (2019) and Pitt et al. (2018), aspects analysed in the advertisements included the colours, message, and characters used as well as the message of the advertisement. (See Appendix 1 for the detailed analysis of the advertising and Appendix 2 for examples of the advertising.)

\section{Focus groups and interviews}

A judgement sample (Denscombe 2010) was deemed appropriate for this study. Specifically, the participants had to belong to Generation Y, be Swedish, and be viewers of on-demand television (i.e., to ensure exposure to the specific advertisements). To access the sample, 50 emails were sent out to a convenience sample of individuals who met these requirements, which were deemed appropriate when researching this topic (Binde 2014). The email introduced the research and contained questions to obtain respondents' views on gambling, online gambling, and online casinos to ensure that they did not hold extreme opinions of casinos and casino advertising to have relatively homogenous groups (e.g., moral objections to gambling or were extremely positive) (Freeman 2006). From the replies received, 18 participants (eight females $[\mathrm{F}]$ and 10 males $[\mathrm{M}]$ ) were invited to partake in one of three focus groups (see Table 3 for details on the participants of the focus groups). The participants gave informed consent to take part in the research. They were shown the 13 advertisements (A1-A13) at the start of the focus group, with the discussion focussing on the advertisement and the outcomes thereof.

Additionally, six semi-structured interviews (average of 67 min each) were conducted using the same judgement criteria, resulting in 400 min of data (see Table 4). These interviews made it possible for the authors to confirm the data. The interviews allowed the authors to achieve saturation and confirmation (Saunders et al. 2012). 
When compiling the interview guide, the questions were formulated using indirect questioning to reduce the potential impact of social desirability bias - that is, when participants do not report accurately on sensitive topics (Fisher 1993).

\section{Data analysis}

The focus groups and interviews were transcribed for further analysis. Thematic analysis was used to identify themes and codes in the data to form a codebook/template that allows for a structured interpretation, starting with theoretically derived themes (Saunders et al. 2012), as it enables an effective analysis since the authors had gathered enough data to have a contextualised and comprehensive understanding (Bazeley 2009). Codes derived from the theory (a priori codes) and emergent codes (derived deductively from the data) were also identified and used (see Table 5) (Stuckey 2015). The data was coded independently and then discussed. Where there were disagreements, these were resolved through discussion (Campbell et al. 2013).

\section{Research ethics}

The topic and industry studied raise important ethical considerations, including whether it is right to advertise gambling and whether gambling should be present in society (Binde 2014). There are various dimensions of the ethics of gambling advertising, with some individuals believing that society would be better without gambling and thus likely to find any type of advertising promoting such action to be wrong (Binde 2014). Throughout this research, the topic was viewed as ethically sensitive, as the authors were aware that the managerial implications might help casino advertising managers to enhance their marketing efforts to the detriment of society.

Table 5 Codes used in the analysis

\begin{tabular}{lll}
\hline A priori codes* & Emergent codes & Specific \\
\hline Content & The attractiveness of the message & Focus on wins \\
& & Rapid payment/cash out \\
& & Focus on female gamblers \\
& & Brand name and slogan \\
Music & Other auditory cues & Sound effects \\
& & Jingle \\
& & Narrative voice
\end{tabular}

Emotional response

Frequency

Advertising ethics

The preconceived notion of the industry

*Celebrity endorsement was not evident in the advertising analysed 


\section{Findings}

\section{The analysis of the advertisements}

The advertisements varied in length, from 10 to $30 \mathrm{~s}$. Humans appeared in five advertisements, while characters appeared in a further two. Four of the advertisements showed women gambling (A2, A5, A8, A9). The sounds used included brands' signature music and jingles. Some advertisements included other sounds, such as falling coins (A1) and sounds of nature (e.g., birds) (A2, A7). Similar to Korn et al. (2005), all the advertisements used bright colours. Other visuals included mobile phones, suggesting the ease and accessibility of gambling. One advertisement had no narration and, of the remaining advertisements, eight were narrated by a male voice. Additional on-screen text included the written ethical warning, as mandated by law, as well as phrases like "big wins", "easy cash outs", and "free spins", as identified in previous research (Derevensky et al. 2010; Håkansson and Widinghoff 2019).

\section{Findings from the interviews}

Some of the participants in both the focus groups and interviews $(N=11)$ had tried online gambling previously. However, none had a history of problem gambling, gambled regularly, or identified themselves as gamblers.

\section{Content factors}

Participants identified various content factors, including the overall attractiveness of the message and the message itself, with a focus on wins and speedy payouts. They described how an unattractive advertisement and website impacted their perceptions, making the brand less attractive. Factors identified as impacting attractiveness included the use of animations and characters (rather than real humans), creating a perception of it being childish. "I find the animated content to be negative and not as appealing" (M1, A11).

The participants agreed that the speed (tempo) and sequences within A5, A1, and A13 affected their ability to process the content. They argued that the brands were attempting to utilise their time slot as much as possible, which created an overload of details in a short period of time. One participant stated:

Very annoying ad. I get a headache from it. There is too much going on, and I get the impression that they are just trying to cram in as much information about the brand as they can. I get stressed and would not choose this brand. (M4, A5).

The participants indicated that the message content focussing on wins led to disbelief and negativity towards the brand, with many viewing it as unethical and 
misleading. One participant described it as a brand having "something to hide" (F7, A13), while another said:

They should not be allowed to show people that win in the games, it is too pushy and makes it look easy to win a lot.... But I would never gamble on their casino. (M11, A6).

The respondents mentioned that many of the advertisements (A4, A6, A12) tried to highlight the ease and speed of cash outs. They viewed this as deceptive and as a reflection of an untrustworthy organisation. "They make it seem so simple, easy and fast to gamble away all of one's money, so the brand is trying to deceive us" (M6, A12). A further participant added:

It bothers me that the logo shows up like it's "pronto" and fast, and then a flash.... It is shallow and the whole thing is just terrible ... just a cheap way to try to get people to gamble. (M1, A6).

Many participants (of both genders) commented on there being a specific focus on female gamblers, especially in advertisements A9, A2, A7, and A13, perceiving this as an attempt to increase the number of female gamblers. One respondent said, "This has a female approach, which does not matter overall, but it would affect my choice of casino since it only shows womanly things it does not attract me" (M10, A9), while another said:

It annoys me that it is so directed towards women, and it is femininely coded. Playing on female stereotypes is so typical. Even the name is femininely coded, then there are two normative white women who are happy, walking around after a shopping spree. (F2, A9).

The name and slogan of the casino were indicated as a reflection of perceived credibility and reliability, with some believing the slogan contributed to perceptions of deception (e.g., A9). Furthermore, the participants required the brand name to be connected to the service itself_- "Their slogan is 'The feeling of winning', that really makes it look like everyone is going to win. So deceiving" (F10, A9). One respondent shared:

I believe that the name of a brand is not very informative, so I would not choose this based on the fact that I don't understand the name and cannot connect it to their service. (M6, A12).

\section{Music and other auditory cues}

While the initial discussion focussed on the music, the participants reacted to the other auditory cues in the advertisement. They often found the music to be too loud, fast, or aimed at a young target market, impacting the response to the advertisement:

I would never go for this brand; the sound is too much. So irritating, and the music was childish, it does not feel like they are trying to address adults. (M13, A6). 
The respondents identified other auditory cues, specifically the sound effects, the narrator's voice, and the jingles. The sounds effects, particularly the sounds of wins, reinforced a distrustful image of the organisation. Some examples used were the sounds of falling coins, while another casino had a "hallelujah" choir in the background-“"They make a winning sound effect ... I hate that" (M12, A12); When she won the jackpot, or got the plastic bag, they had such annoying sound effect, like a 'hallelujah' moment" (F1, A2).

Participants also commented extensively on the narrator's voice in the advertisement. They perceived this as being intrusive and also reacted to the authoritative tone of the (male) voice- "I hate the typical 'gamble more' manly voice. It is intrusive and unreliable" (M5, A1). For some participants, the narrative voice in A3 was associated with other advertisements:

When I hear this voice, I immediately think of commercials. I associate this commanding voice with ads ... I get pissed off that the voice is so intrusive, and I just feel that I want them to leave me alone. You are not talking to me like I am a normal person, it is just a voice that is there. (M11, A3).

Seven of the advertisements presented in the study contained jingles. Some of the participants identified these as being annoying or giving a childish impression of the brand and advertisement. "I kind of liked this one until their brand came into the ad with their jingle. It made it seem childish" (F2, A7).

Even though the participants felt positively towards the advertisement, the jingle in A9 elicited negative reactions:

I instantly find this advert annoying, and when you hear them singing all the time it gets to you. It is not the advertising itself, but the jingle that would get to me. $(\mathrm{F} 3, \mathrm{~A} 9)$.

\section{Emotional response}

The 13 different casino advertisements generated diverse responses from the study's participants, with their impression of the advertisement influencing their perception of the brand and the resulting behavioural choices. "I get annoyed at the company because I am annoyed by their ad. I would then not visit their casino based on the fact that they already annoyed me" (F6, A5). The participants were more negative when they perceived the advertisement to be misleading-for example, when it was perceived as unrealistic and unfair.

They have the cartoon, okay cool, but then all of sudden you are in the game, and it feels out of place. Why would they show me this? I would never have picked them. (M13, A13).

Everything looks so glamorous, and then it just rains money. They are trying to make people believe that if they just gamble, they will get a new meaning in their life. I hate these types of advertisements as soon as I see them. (F8, A1).

Regarding the frequency of the advertisement, the participants highlighted the frequency of both casino advertisements in general and these brands, sharing that 
the frequency of broadcasts impacted their attitude towards the advertisement and the brand. While the frequency of the advertisements provoked annoyance, longer advertisements that were repeated were perceived as being more annoying. One participant stated, "I would have been annoyed if this advertisement was played more than once, that would have made me look at the company negatively" (M3, A1); while a different respondent had the following to say:

I would be annoyed if this one reoccurred. And it is very long, which would annoy me even more, if this came up during a commercial break it would really irritate me. (F11, A12).

\section{Emergent codes}

Despite ensuring the sample did not hold extreme views on gambling, the participants raised two issues related to casino advertising. The first was the ethics of casino advertising and second was the broader perceptions of the industry, specifically the lengths to which the advertisements went to create a normalised impression of gambling.

They really try to normalise gambling as an everyday activity. It is odd that she is just at a cafe and gambling whilst drinking her coffee. I do not think that this portrays a real casino player at all. (F11, A9).

The accessibility of online casinos was also identified and linked to the ubiquitous nature of mobile phones where online gambling is made simple, which can lead to the development of an unhealthy habit and possibly even an addiction.

They use a phone because everyone has one, they make it seem very accessible. They try to tell us that if we just own a phone, we can win money. It is horrible because people who do not have a critical mindset will gamble and might get addicted. It is a trigger! And then, they even have the support line, so they know about it. (F7, A10).

The moral response to advertisement A2 was coloured by the brand behind the advertisement, as it was viewed as questionable for state-owned online casinos to engage in advertising, as participants held these casinos to higher standards.

I find this a bit disturbing, and this is supposed to be a serious gambling company, as they are state-owned, they should protect their customers. The fact that they engage in such advertising is disturbing. (F9, A2).

Some respondents expressed that online casino advertisements should be further regulated so that wins can no longer be demonstrated, as this was thought to take advantage of those already addicted to gambling. Additionally, many participants tried to ignore these advertisements due to the perceptions of the industry itself:

The feelings and thoughts that I already have about casino commercials make it so that I do not really take them in, no matter how often I see them. I just try to ignore them. (M9, A8). 


\section{Discussion}

Due to the ubiquitous nature of casino advertising worldwide and the potential impact on avoidance, the purpose of this study was to explore the use of creative strategies in casino advertising and how it contributes to the avoidance of online casinos, specifically among Swedish Generation Y consumers. Two research questions were formulated to attain the purpose of the research. Research question 1 focussed on the creative strategies used in casino adverts, namely what advertising strategies are used in gambling advertising. The advertisements for online casinos reflect creative strategies similar to those utilised in sports betting advertisements using both humans and characters (Pitt et al. 2018). Sounds, including music and other supporting auditory cues, are used to communicate with the viewer. Similar to Korn et al. (2005) and Pitt et al. (2018), the use of predominantly male voice-overs was identified. As established in previous research, phrases like "big wins", "easy cash outs", and "free spins" appeared in the advertisement (Derevensky et al. 2010; Håkansson and Widinghoff 2019; Korn et al. 2005; Pitt et al. 2018).

Research question 2 examined how these advertising strategies affect the avoidance of casino brands. The findings show the impact of these advertisements on the decision to avoid online casino brands. Participants made statements like: "I would definitely choose another brand"; "I get stressed and would not choose this brand"; "I would never gamble at their casino"; "It would affect my choice of casino"; and "I could never gamble there". Regarding advertising content, the participants commented on unappealing advertisements, specifically those using animation and too much information during a short time, which put the viewer under cognitive pressure. Wins are promoted in casino advertising as part of the positive framing of the advertising message (Abarbanel et al. 2017; Korn et al. 2005; Kroon 2021; Torrance, et al. 2021a), yet a lack of realism was viewed as deceptive and distasteful, impacting the response to the advertising and the brand (Berndt et al. 2019; Labrador et al. 2021; Xie et al. 2015). Similarly, the promise of rapid payment (cash outs) contributed to negative responses to the advertisement, resulting in disbelief and distrust in the brand, as identified in previous research (Torrance et al. 2021b). The emphasis on female gamblers as characters in the advertisements was perceived by both genders as encouraging females to gamble, specifically through unrealistic, stereotypical situational portrayals. The use of female gamblers differs from previous studies, where men were the primary characters and women were portrayed in fantasy situations (Deans et al. 2016; Korn et al. 2005). Furthermore, negative responses developed when a brand name and slogan had a vague connection to the service (focussing on wins), as it led to confusion and a perceived non-existent relationship between the brand name and service, leading to negative reactions to the brand (Odoom et al. 2019). The message of the advertisements was similar to those identified in other studies (Deans et al. 2016; Derevensky et al. 2010; Håkansson and Widinghoff 2019), although when customers found the advertisements' content distasteful, it led to avoidance.

Attention has been paid to music in advertising due to its ability to influence listeners' emotions and behaviour (Alpert et al. 2005). Similar to Berndt et al. (2019) 
and Odoom et al. (2019), this study finds that aspects associated with music influence brand avoidance. It is not only the volume of the music, but also the genre of music that needs to be considered. For example, the use of "youth-orientated" music (Monaghan et al. 2008) is negatively perceived, despite the age of the participants (Generation Y). An additional music-related strategy used in advertising is jingles. Jingles, which are the "catchy songs about a product or service" (Belch and Belch 2015 p. 714), can provide an additional dimension to the advertisement (Gupta 2013), increasing awareness and brand retention due to its impact on the memory (Shakil and Siddiqui 2019; Taylor 2015). Participants believed that jingles were more common in casino advertisements than in other advertisements, which might contribute to negative reactions to their use.

Audiovisual cues include not only the music, but the sound effects and narrations used in the advertisement. This study's chosen advertising, sound effects like slot machines, and other win-related cues that are used in casino advertising reinforced negative perceptions of the casino. The narrators of the advertisements were largely male. While male voice-overs are widely used in advertising (Korn et al. 2005), in this study's ads, they were perceived as the "stereotypical" voice, drawing attention away from the advertisement, thus impacting the avoidance decision.

Advertising can produce cognitive and emotional responses towards the advertisement and the brand being advertised by changing beliefs about the product and creating positive or negative emotions (Belch and Belch 2015; Kavaliauskè and Simanavičiūtė 2015). A negative response was evident when participants perceived the advertisement as annoying and/or irritating, impacting their decision to avoid the brand (Kavaliauskè and Simanavičiūtè 2015). Complex advertisements containing a high amount of content in a short period generally led to a negative response, as the participants could not comprehend the information (Kirmeyer 1988). Presenting the glamourous aspects associated with gambling caused a range of negative emotional responses, including irritation and strong negative emotions (e.g., hate) especially when the advertisements were viewed as deceptive, despite not contravening national advertising guidelines.

Although advertising frequency contributes to recall (Binde 2014), participants observed an increased frequency of gambling advertising (Torrance et al. 2021b) and disliked casino advertising due to its frequency (Derevensky et al. (2010), contributing to the avoidance of the brands (Chih-Chung et al. 2012; Dens et al. 2008; Knittel et al. 2016). While the advertising met the regulatory requirements, participants identified aspects that they viewed as unethical within the advertisements, where normalisation and a false reality (i.e., not a real scenario) are presented (Monaghan et al. 2008; Torrance et al. 2021b), which impact how they evaluate the brand (Xie et al. 2015). Gambling has been argued to be a public health issue (Gainsbury et al. 2013), and participants indicated that the normalisation of gambling in advertisements contributed to brand avoidance. Some brands (e.g., A2) were held to a different standard, as they are state-owned and participants believed they should be more responsible. As participants had a preconceived negative perception of the specific industry, these advertisements could irritate them more (Aaker and Bruzzone 1985). 


\section{Theoretical and managerial implications}

Theoretically, this study contributes to several areas. First, while the study focuses on Swedish Generation Y consumers, it contributes to increasing the international understanding of advertising among this cohort outside of the UK and Australia, finding support for some of the views held in these countries (Torrance et al. 2021a). Second, there is increased awareness among consumers that consumption has negative aspects that are also "largely unexplored by researchers" (Azevedo 2020 p. 251). Accordingly, the findings identify the importance of advertising ethics and perceptions of the industry, which are relevant to online casinos. Third, this study provides additional insights into the effect of advertising avoidance on avoidance behaviours in another product category. Previous research has investigated the role of advertising avoidance towards a broad range of products (Odoom et al. 2019), such as fashion (Lee et al. 2017; Lin et al. 2020; Vajkai and Zsóka 2020), mobile phones (Mostert et al. 2017; Mostert et al. 2021), and service brands (Berndt et al. 2019). This study shows that advertising can contribute to brand avoidance in the case of online casinos, expanding the understanding of advertising avoidance and its outcomes. Moreover, the study contributes to the theoretical development of the nature of advertising avoidance by expanding the term suggested in previous research (Knittel et al. 2016). After careful consideration of previous research and our data, we propose that "auditory cues" is a more fitting umbrella term for use in future research, as this includes not only music, but also sound effects, the narrator's voice, and jingles.

Practically, the findings suggest that the various aspects identified in the study are critical for the creative parties involved in designing and implementing advertising, due to their impact on the willingness of the Generation Y participants to support the brand. These aspects include the message formulation, the choice of auditory stimuli, and the scheduling frequency of advertising. The use of the winning message, which is a theme in many casino advertisements (Pitt et al. 2018; Torrance et al. 2021a), is perceived as unrealistic and a reason for avoidance.

Pre-testing of advertising can reduce the potential negative reaction to advertisements. Additionally, the study emphasises the importance of the ethical perspectives of this cohort group that were used to evaluate not only the advertising, but also the industry and its operating principles. This is aligned with the increasing importance of ethical issues to consumers, requiring organisations to be more aware of their marketing decisions (Azevedo 2020). While there are clear ethical guidelines formulated by governments to regulate this advertising, the perceptions of the participants could suggest additional aspects for regulators to consider.

Participants' perceptions of the advertising being deceptive had an impact on the brand and associated attitudes and behaviours. The perception that these advertisements are deceptive and do not portray an actual online gambler suggests that casinos should use more realistic scenarios to differentiate themselves. Furthermore, the ethical management of the gambling industry within broader society requires attention due to the potential for additional regulation to limit the perceived normalisation of gambling within these advertisements. Although 
advertising codes have been formulated to limit the negative effects (Binde 2014), the possible need for further regulation was identified by the participants.

\section{Conclusions, limitations, and future research}

The growth of online casinos has resulted in increasing advertising spending to market these brands. Advertising is designed to impact the consumer, yet while the impact tends to be positive, this study provides clarity on how they can also produce a negative outcome (e.g., decision not to buy or support) for online casinos.

While efforts were made to recruit participants who did not hold extreme views of gambling or online casinos, the potentially controversial nature of the product category (Binde 2014) could have resulted in the expression of more extreme views. The selection and viewing of the advertisements could also serve as a limitation due to their length and them being shown in an unrealistic setting. The sample of advertising was 1 week, limiting the number of casino advertisements included in the study. As no advertisements contained any celebrity endorsement, it is not possible to argue for or against its contributions to brand avoidance in online casino advertisements. This study focussed solely on advertising, thereby eliminating other components of the integrated marketing communication mix, which also impacts attitudes and behaviours.

This research presents various future research opportunities. This study explored brand avoidance among participants who did not identify themselves as gamblers, but individuals identifying as gamblers could perceive advertising differently (Hanss et al. 2015). Research among millennials in other countries (apart from the UK and Australia) is also recommended due to potential cultural differences in gambling advertising. Moreover, expanding the research to include broader cohort groups is recommended as well as evaluating its effect quantitatively (Odoom et al. 2019). Additionally, expanding the research to other types of gambling, such as sports betting, is recommended.

Supplementary Information The online version contains supplementary material available at https://doi. org/10.1007/s43546-021-00185-z.

Funding Open access funding provided by Jönköping University. No funding was received to assist with the preparation of this manuscript.

\section{Declarations}

Conflict of interest The authors have no conflicts of interest to declare that are relevant to the content of this article.

Ethical approval The project was registered with the appropriate university body for research. All research was conducted in accordance with GDPR guidelines, including collection and storage of the data.

Informed consent All participants provided informed consent prior to their participation. 
Open Access This article is licensed under a Creative Commons Attribution 4.0 International License, which permits use, sharing, adaptation, distribution and reproduction in any medium or format, as long as you give appropriate credit to the original author(s) and the source, provide a link to the Creative Commons licence, and indicate if changes were made. The images or other third party material in this article are included in the article's Creative Commons licence, unless indicated otherwise in a credit line to the material. If material is not included in the article's Creative Commons licence and your intended use is not permitted by statutory regulation or exceeds the permitted use, you will need to obtain permission directly from the copyright holder. To view a copy of this licence, visit http://creativecommons.org/licen ses/by/4.0/.

\section{References}

Aaker DA (1996) Building strong brands: building, measuring, and managing brand equity. The Free Press, New York

Aaker DA, Bruzzone DE (1985) Causes of irritation in advertising. J Mark 49(2):47-57. https://doi. org/10.2307/1251564

Abarbanel B, Gainsbury SM, King D, Hing N, Delfabbro PH (2017) Gambling games on social platforms: how do advertisements for social casino games target young adults? Policy Internet 9(2):184-209. https://doi.org/10.1002/poi3.135

Alpert MI, Alpert JI, Maltz EN (2005) Purchase occasion influence on the role of music in advertising. J Bus Res 58(3):369-376. https://doi.org/10.1016/S0148-2963(03)00101-2

Alwitt LF, Mitchell AA (1985) Psychological processes and advertising effects: theory, research, and applications. Lawrence Erlbaum Associates, Hillsdale

Alwreikat A, Rjoub H (2020) Impact of mobile advertising wearout on consumer irritation, perceived intrusiveness, engagement and loyalty: a partial least squares structural equation modelling analysis. S Afr J Bus Manag 51(1):1-11. https://doi.org/10.4102/sajbm.v51i1.2046

Amine A, Gicquel Y (2011) Rethinking resistance and anti-consumption behaviours in the light of the concept of deviance. Eur J Mark 45(11/12):1809-1819. https://doi.org/10.1108/0309056111 1167450

Apaolaza-Ibáñez V, Zander M, Hartmann P (2010) Memory, emotions and rock'n'roll: the influence of music in advertising, on brand and endorser perception. Afr J Bus Manag 4(17):3805-3816. https://doi.org/10.5897/AJBM.9000405

Apéria T, Back R (2004) Brand relations management: bridging the gap between brand promise and brand delivery. Copenhagen Business School Press, Liber

Azevedo A (2020) Recognizing consumerism as an "illness of an empty soul": a catholic morality perspective. Psychol Mark 37(2):250-259. https://doi.org/10.1002/mar.21267

Babin BJ, Zikmund WG (2016) Exploring marketing research. Cengage Learning, Boston

Bazeley P (2009) Analysing qualitative data: more than 'identifying themes. Malays J Qual Res 2(2):6-22

Belch GE, Belch MA (2015) Advertising and promotion: an integrated marketing communications perspective. McGraw-Hill/Irwin, New York

Bell P (2001) Content analysis of visual images. Van Leeuwen C. Jewitt The Handbook of Visual Analysis. Sage, London, pp 10-34

Berndt A, Petzer DJ, Mostert P (2019) Brand avoidance-a services perspective. Eur Bus Rev 31(2):179_ 196. https://doi.org/10.1108/EBR-02-2017-0033

Binde P (2014) Gambling advertising: a critical research review. The Responsible Gambling Trust, London

Binde P, Romild U (2019) Self-reported negative influence of gambling advertising in a Swedish population-based sample. J Gambl Stud 35(2):709-724. https://doi.org/10.1007/s10899-018-9791-X

Bloemer J, Brijs K, Kasper H (2009) The CoO- ELM model; a theoretical framework for the cognitive processes underlying country of origin-effects. Eur J Mark 43(1/2):62-89. https://doi.org/10.1108/ 03090560910923247

Bolton RN, Drew JH (1991) A multistage model of customers assessments of service quality and value. J Consum Res 17(4):375-384 
Bramley S, Dibben N, Rowe R (2016) The utilisation of music by casino managers: an interview study. J Gambl Stud 32(4):1127-1141. https://doi.org/10.1007/s10899-016-9604-z

Butkowski CP, Tajima A (2017) A critical examination of visualized femininity: selective inheritance and intensification of gender posing from historical painting to contemporary advertising. Fem Media Stud 17(6):1037-1055. https://doi.org/10.1080/14680777.2017.1300830

Cambefort M, Pecot F (2020) Theorizing rightist anti-consumption. Mark Theory 20(3):385-407. https:// doi.org/10.1177/1470593119895792

Campbell JL, Quincy C, Osserman J, Pedersen OK (2013) Coding in-depth semistructured interviews: problems of unitization and intercoder reliability and agreement. Sociol Methods Res 42(3):294320. https://doi.org/10.1177/0049124113500475

Chih-Chung C, Chang C, Lin LW-C (2012) The effect of advertisement frequency on the advertisement attitude-the controlled effects of brand image and spokesperson's credibility. Proced Soc Behav Sci. https://doi.org/10.1016/j.sbspro.2012.09.1197

Clemens F, Hanewinkel R, Morgenstern M (2017) Exposure to gambling advertisements and gambling behavior in young people. J Gambl Stud 33(1):1-13. https://doi.org/10.1007/s10899-016-9606-X

Coulter KS (2009) Enough it enough! or is it? Factors that impact switching intentions in extended travel service transactions. J Travel Tour Mark 26(2):144-155. https://doi.org/10.1080/1054840090 2864636

Dahlén M, Rosengren S (2016) If advertising won't die, what will it be? Toward a working definition of advertising. J Advert 45(3):334-345. https://doi.org/10.1080/00913367.2016.1172387

Dall'Olmo Riley F, De Chernatony L (2000) The service brand as relationships builder. Br J Manag 11(2):137-150. https://doi.org/10.1111/1467-8551.t01-1-00156

De Pelsmacker P, Van Den Bergh J (1999) Advertising content and irritation: a study of 226 TV commercials. J Int Consum Mark 10(4):5-27. https://doi.org/10.1300/J046v10n04_02

Deans EG, Thomas SL, Daube M, Derevensky J, Gordon R (2016) Creating symbolic cultures of consumption: an analysis of the content of sports wagering advertisements in Australia. BMC Public Health 16(208):1-11. https://doi.org/10.1186/s12889-016-2849-8

Denegri-Knott J, Zwick D, Schroeder JE (2006) Mapping consumer power: an integrative framework for marketing and consumer research. Eur J Mark 40(9/10):950-9971. https://doi.org/10.1108/03090 560610680952

Dens N, De Pelsmacker P, Janssens W (2008) Exploring consumer reactions to incongruent mild disgust appeals. J Mark Commun 14(4):249-269. https://doi.org/10.1080/13527260802141231

Denscombe M (2010) Good research guide : for small-scale social research projects. Open University Press, Maidenhead

Derevensky J, Sklar A, Gupta R, Messerlian C (2010) An empirical study examining the impact of gambling advertisements on adolescent gambling attitudes and behaviors. Int J Ment 8(1):21-34. https://doi.org/10.1007/s11469-009-9211-7

Dolliver M (2010) When marketing leads to brand avoidance. Brandweek 51(12):20

Fill C, Turnbull SL (2016) Marketing communications: brands, experiences and participation. Pearson, Harlow

Fisher RJ (1993) Social desirability bias and the validity of indirect questioning. J Consum Res 20(2):303-315

Fournier S, Breazeale M, Fetscherin M (2012) Consumer-brand relationships: theory and practice. Routledge, Adington

Freeman T (2006) 'Best practice' in focus group research: making sense of different views. J Adv Nurs 56(5):491-497. https://doi.org/10.1111/j.1365-2648.2006.04043.x

Friberg Wennerberg J (2018) Dolph lundgren tar över rollen efter frank andersson. Dolph Lundgren takes over the roll after Frank Andersson. https://www.hant.se/noje/dolph-lundgren-tar-over-rollen-efterfrank-andersson/. Accessed 14 Jan 2019

Frick H (2018) Studie: Webb-tv större än linjär-tv. Study: Web TV larger than TV. https://www.dagen smedia.se/medier/rorligt/studie-webb-tv-storre-an-linjar-tv-6899060. Accessed 15 Feb 2018

Gainsbury SM, Parke J, Suhonen N (2013) Consumer attitudes towards Internet gambling: perceptions of responsible gambling policies, consumer protection, and regulation of online gambling sites. Comput Hum Behav 29(1):235-245. https://doi.org/10.1016/j.chb.2012.08.010

Garcia-Bardidia R, Nau JP, Rémy E (2011) Consumer resistance and anti-consumption. Eur J Mark 45(11/12):1789-1798. https://doi.org/10.1108/03090561111167423 
Gavriel Fried B, Teichman M, Rahav G (2010) Adolescent gambling: temperament, sense of coherence and exposure to advertising. Addict Res Theory 18(5):586-598. https://doi.org/10.3109/16066 350903428945

Griffiths M, Barnes A (2008) Internet gambling: an online empirical study among student gamblers. Int J Ment 6(2):194-204. https://doi.org/10.1007/s11469-007-9083-7

Gupta V (2013) Ad. jingles: brand recall. SCMS J Indian Manag 10(2):78-89

Håkansson A, Widinghoff C (2019) Television gambling advertisements: extent and content of gambling advertisements with a focus on potential high-risk commercial messages. Addict Behav Rep 9(100182):1-8. https://doi.org/10.1016/j.abrep.2019.100182

Hanss D, Mentzoni RA, Griffiths MD, Pallesen S (2015) The impact of gambling advertising: problem gamblers report stronger impacts on involvement, knowledge, and awareness than recreational gamblers. Psychol Addict Behav 29(2):483-491. https://doi.org/10.1037/adb0000062

Harris Interactive (2010) Over one-third of americans will not purchase a brand because of a distasteful advertisement. https://theharrispoll.com/over-one-third-of-americans-will-not-purchase-a-brandbecause-of-a-distasteful-advertisement-03-26-2010/. Accessed 25 Jan 2021

Haytko DL, Clark RA, Hermans CM, Parker RS (2018) Examining the dimensionality in global attitudes toward advertising: a comparison of perceptions of Chinese and United States consumers. J Int Consum Mark 30(2):85-97. https://doi.org/10.1080/08961530.2017.1376603

Henriksen J, Hornebrant M (2019) Casino royale: brand avoidance and advertising among Generation Y in Sweden (M.Sc.) Jönköping University Jönköping, Sweden. Retrieved from https://www. diva-portal.org/smash/record.jsf?pid=diva2\%3A1319387\&dswid=1014. Accessed 20 Oct 2021

Hing N, Cherney L, Blaszczynski A, Gainsbury SM, Lubman DI (2014) Do advertising and promotions for online gambling increase gambling consumption? An Exploratory Study. Int Gambl Stud 14(3):394-409. https://doi.org/10.1080/14459795.2014.903989

Hing N, Cherney L, Gainsbury SM, Lubman DI, Wood RT, Blaszczynski A (2015) Maintaining and losing control during Internet gambling: a qualitative study of gamblers' experiences. New Media Soc 17(7):1075-1095. https://doi.org/10.1177/1461444814521140

Hing N, Russell AMT, Lamont M, Vitartas P (2017) Bet anywhere, anytime: an analysis of Internet sports bettors' responses to gambling promotions during sports broadcasts by problem gambling severity. J Gambl Stud 33(4):1051-1065. https://doi.org/10.1007/s10899-017-9671-9

Hing N, Russell AM, Thomas A, Jenkinson R (2019) Wagering advertisements and inducements: exposure and perceived influence on betting behaviour. J Gambl Stud 35(3):793-811. https:// doi.org/10.1007/s10899-018-09823-y

Hogg M, Banister E (2001) Dislikes, distastes and the undesired self: conceptualising and exploring the role of the undesired end state in consumer experience. J Mark Manag 17(1-2):73-104. https://doi.org/10.1362/0267257012571447

Iyer R, Muncy JA (2009) Purpose and object of anti-consumption. J Bus Res 62(2):160-168. https:// doi.org/10.1016/j.jbusres.2008.01.023

Kavaliauskè M, Simanavičiūtė E (2015) Brand avoidance: relations between brand-related stimuli and negative emotions. Organ Mark Emerg Econ 6(1):44-77. https://doi.org/10.15388/omee.2015.6. 1.14227

Kirmeyer SL (1988) Coping with competing demands: interruption and the type A pattern. J Appl Psychol 73(4):621-629. https://doi.org/10.15388/omee.2015.6.1.14227

Knittel Z, Beurer K, Berndt A (2016) Brand avoidance among Generation Y consumers. Qual Mark Res 19(1):27-43. https://doi.org/10.1108/QMR-03-2015-0019

Korn D, Hurson T, Reynolds J (2005) Commercial gambling advertising: Possible impact on youth knowledge, attitudes, beliefs and behavioural intentions. Ontario Problem Gambling Research Centre, Guelph

Kozinets RV, Handelman JM (2004) Adversaries of consumption: consumer movements, activism, and ideology. J Consum Res 31(3):691-704. https://doi.org/10.1086/425104

Kroon Å (2021) What's high-risk about online casino advertisements for women gamblers? Paper presented at the NordMedia Conference 2021, (Virtual Conference), August 18-20

Labrador F, Bernaldo-de-Quirós M, Sánchez-Iglesias I, Labrador M, Vallejo-Achón M, FernándezArias I, Estupiñá F (2021) Advertising games of chance in adolescents and young adults in Spain. J Gambl Stud. https://doi.org/10.1007/s10899-020-09988-5

Lantos GP, Craton LG (2012) A model of consumer response to advertising music. J Consum Mark 29(1):22-42. https://doi.org/10.1108/07363761211193028 
Lee MSW (2008) Brands we love to hate: an exploration of brand avoidance (Ph.D) University of Auckland. Retrieved from https://researchspace.auckland.ac.nz/handle/2292/2556. Accessed 17 July 2016

Lee MSW, Conroy DM, Motion J (2009a) Brand avoidance: a negative promises perspective. NAadvances in consumer research, vol 36. Association for Consumer Research, Duluth, pp 421-429

Lee MSW, Fernandez KV, Hyman MR (2009b) Anti-consumption: an overview and research agenda. J Bus Res 62(2):145-147. https://doi.org/10.1016/j.jbusres.2008.01.021

Lee MSW, Motion J, Conroy DM (2009c) Anti-consumption and brand avoidance. J Bus Res 62(2):169-180. https://doi.org/10.1016/j.jbusres.2008.01.024

Lee MSW, Roux D, Cherrier H, Cova B (2011) Anti-consumption and consumer resistance: concepts, concerns, conflicts and convergence. Eur J Mark. https://doi.org/10.1108/ejm.2011.00745kaa. 001

Lee MSW, Seifert M, Cherrier H (2017) Anti-consumption and governance in the global fashion industry: transparency is key. Governing corporate social responsibility in the apparel industry after rana plaza. Springer, Berlin, pp 147-174

Lin L, Xu Y, Tao Q (2020) Motivational drivers of Chinese consumers' brand avoidance behaviours: a perspective of sportswear. Int J Fash Des 13(1):45-57. https://doi.org/10.1080/17543266.2020. 1719435

McCracken G (1989) Who is the celebrity endorser? Cultural foundations of the endorsement process. J Consum Res 16(3):310. https://doi.org/10.1086/209217

McMillen J (2005) Understanding gambling history, concepts and theories. J. McMillen gambling cultures studies in history and interpretation. Routledge, London

McMullan JL, Kervin M (2012) Selling Internet gambling: advertising, new media and the content of poker promotion. Int J Ment 10(5):622-645. https://doi.org/10.1007/s11469-011-9336-3

Mehta A (2000) Advertising attitudes and advertising effectiveness. J Advert Res 40(3):67-72. https:// doi.org/10.2501/JAR-40-3-67-72

Miller G (2018) Gambling companies spend $£ 1.2$ billion marketing online, five times more than on television ads. https://europeangaming.eu/portal/press-releases/2018/11/28/33678/gambling-compa nies-spend-1-2-billion-marketing-online-five-times-more-than-on-television-ads/. Accessed 6 Sept 2021

Monaghan S, Derevensky J, Sklar A (2008) Impact of gambling advertisements and marketing on children and adolescents: policy recommendations to minimise harm. J Gambl. https://doi.org/10. 4309/jgi.2008.22.7

Mostert P, Petrou S, Petzer D, Berndt A (2017) A quantitative exploration of service brand avoidance and its antecedents among CNO customers-an emerging market perspective. Int J Serv Oper Manag 39(4):477-494

Mostert P, Petrou S, Petzer DJ, Berndt A (2021) A quantitative exploration of service brand avoidance and its antecedents. Int J Serv Oper. https://doi.org/10.1504/IJSOM.2020.10023973

Myndigheten för Press RoT (2018) Mediekonsumtion Media Consumption. Myndigheten för Press, Stockholm, Radio och TV https://www.mprt.se/sv/mer-om-media/medieutveckling/mediekonsu mtion/. Accessed 7 Apr 2019

Noble SM, Haytko DL, Phillips J (2009) What drives college-age Generation Y consumers? J Bus Res 62(6):617-628. https://doi.org/10.1016/j.jbusres.2008.01.020

Nyemcsok C, Thomas SL, Bestman A, Pitt H, Daube M, Cassidy R (2018) Young people's recall and perceptions of gambling advertising and intentions to gamble on sport. J Behav Addict 7(4):10681078. https://doi.org/10.1556/2006.7.2018.128

Oakes S (2007) Evaluating empirical research into music in advertising: a congruity perspective. J Advert Res 47(1):38-50. https://doi.org/10.2501/S0021849907070055

Odoom R, Kosiba JP, Djamgbah CT, Narh L (2019) Brand avoidance: underlying protocols and a practical scale. J Prod Brand Manag 28(5):586-597. https://doi.org/10.1108/JPBM-03-2018-1777

Oumlil AB, Balloun JL (2020) Millennials' attitude toward advertising: an international exploratory study. Young Consum 21(1):17-34. https://doi.org/10.1108/YC-10-2018-0865

Pentina I, Amos C (2011) The Freegan phenomenon: anti-consumption or consumer resistance? Eur J Mark 45(11/12):1768-1778. https://doi.org/10.1108/03090561111167405

Petrovici D, Marinov M (2007) Determinants and antecedents of general attitudes towards advertising: a study of two EU accession countries. Eur J Mark 41(3-4):307-326. https://doi.org/10.1108/03090 560710728354 
Pitt H, Thomas SL, Bestman A, Randle M, Daube M (2018) Do betting advertisements contain attention strategies that may appeal to children? An interpretative content analysis. Health Promot J Aust 29(3):265-273. https://doi.org/10.1002/hpja.12

Rindell A, Strandvik T, Wilén K (2014) Ethical consumers' brand avoidance. J Prod Brand Manag 23(2):114-120. https://doi.org/10.1108/JPBM-09-2013-0391

Sabri O, Obermiller C (2012) Consumer perception of taboo in ads. J Bus Res 65(6):869-873. https://doi. org/10.1016/j.jbusres.2011.01.009

Sandage CH, Leckenby JD (1980) Student attitudes toward advertising: institution vs instrument. J Advert 9(2):29-44. https://doi.org/10.1080/00913367.1980.10673316

Sandıkcı Ö, Ekici A (2009) Politically motivated brand rejection. J Bus Res 62(2):208-217. https://doi. org/10.1016/j.jbusres.2008.01.028

Saunders M, Lewis P, Thornhill A (2012) Research methods for business students. Pearson, Harlow

Shakil A, Siddiqui DA (2019) How jingles in advertising affect retention and recall of the product. Int J Thesis Proj Diss 7(2):20-29. https://doi.org/10.2139/ssrn.3302192

Sklar A, Derevensky JL (2011) Way to play: analyzing gambling ads for their appeal to underage youth. Can J Commun 35(4):533-554. https://doi.org/10.22230/cjc.2010v35n4a2331

Spel Inspektionen (2018) Nätkasino ökar, nätpoker minskar. Online casino increases, online poker decreases. https://www.spelinspektionen.se/om-oss/statistik/statistiknytt/natkasino-okar-natpokerminskar/. Accessed 15 Dec 2020

Spel Inspektionen (2019a) Män födda 1990 står för flest antal självavstängda i Spelpaus.se. Men born in 1990 account for the largest number of self-excluded in Spelpaus.se. https://www.spelinspektionen. se/om-oss/statistik/statistiknytt/man-fodda-1990-star-for-flest-antal-sjalvavstangda-i-spelpaus.se/. Accessed 7 Apr 2019

Spel Inspektionen (2019b) Allmänheten om spel 2019. The public on games 2019. https://www.speli nspektionen.se/press/nyhetsarkiv/farre-spelar-om-pengar-allmanheten-om-spel-2019/. Accessed 17 Feb 2020

Stuckey HL (2015) The second step in data analysis: coding qualitative research data. J Soc Health Diabetes 3(01):007-010. https://doi.org/10.4103/2321-0656.140875

Suh E, Alhaery M, Abarbanel B, McKenna A (2017) Examining millennials' online gambling behavior: a comparison of generational differences. J Hosp Tour Technol 8(3):314-336. https://doi.org/10. 1108/JHTT-03-2017-0024

Swani K, Weinberger MG, Gulas CS (2013) The impact of violent humor on advertising success: a gender perspective. J Advert 42(4):308-319. https://doi.org/10.1080/00913367.2013.795121

Taylor CR (2015) The imminent return of the advertising jingle. Int J Advert 34(5):717-719. https://doi. org/10.1080/02650487.2015.1087117

Torrance J, John B, Greville J, O'Hanrahan M, Davies N, Roderique-Davies G (2021a) Emergent gambling advertising; a rapid review of marketing content, delivery and structural features. BMC Public Health 21(1):1-13. https://doi.org/10.1186/s12889-021-10805-w

Torrance J, Roderique-Davies G, Thomas SL, Davies N, John B (2021b) 'It's basically everywhere': young adults' perceptions of gambling advertising in the UK. Health Prom Int 36(4):976-988. https://doi.org/10.1093/heapro/daaa126

Vajkai ÉK, Zsóka Á (2020) Brand avoidance behaviour of Gen Z towards fast fashion brands. Bp Bus J 51(5):39-50. https://doi.org/10.14267/VEZTUD.2020.05.04

Xie G-X, Madrigal R, Boush D (2015) Disentangling the effects of perceived deception and anticipated harm on consumer responses to deceptive advertising. J Bus Ethics 129(2):281-293. https://doi. org/10.1007/s10551-014-2155-2

Zavestoski S (2002) The social-psychological bases of anticonsumption attitudes. Psychol Mark 19(2):149-165. https://doi.org/10.1002/mar.10007 